\title{
Tributes to Daniel H. Teitelbaum, MD, PhD
}

Journal of Parenteral and Enteral

Nutrition

Volume 40 Number 8

November 2016 1079-1086

(C) 2016 American Society

for Parenteral and Enteral Nutrition DOI: $10.1177 / 0148607116671942$

jpen.sagepub.com

hosted at

online.sagepub.com

@SAGE

Ainsley Malone, MS, RD, LD, CNSC, FAND, FASPEN ${ }^{4}$

Gordon S. Sacks, PharmD, BCNSP, FCCP ${ }^{5}$; M. Molly McMahon, MD $^{6}$;

Marion F. Winkler, PhD, RD, LDN, CNSC, FASPEN ${ }^{7}$; Kris M. Mogensen, MS, RD, LDN, CNSC ${ }^{8}$;

Arlet Kurkchubasche, MD ${ }^{9}$; Meghan A. Arnold, MD $^{10}$; Hua Yang, MD, PhD ${ }^{11}$;

Allison B. Blackmer, PharmD, BCPS ${ }^{12}$; Carol Braunschweig, PhD, RD ${ }^{13}$;

Theresa Han-Markey, MS, RD ${ }^{14}$; M. Luisa Partipilo, PharmD, BCNSP ${ }^{14,15, *}$;

Mary Beth Harris, MPH, RD, CSP, CNSC ${ }^{15, *}$; Deb Kovacevich, MPH, BSN, RN ${ }^{16}$;

Bonnie Peters, $\mathbf{R N}^{17}$; Alexis Cantwell; and Mary Ann Fithian

Our ASPEN president in 2014, Daniel H. Teitelbaum, MD, $\mathrm{PhD}$, was truly a stellar leader, a gifted investigator and mentor, a global diplomat, and a dedicated and trusted pediatric surgeon. In the series of statements that follow, you will hear reflections from many individuals who reflect on different aspects of Dan's professional life.

\section{Charlene Compher, PhD, RD, CNSC, LDN, FASPEN; ASPEN President 2016-2017}

I was privileged to be a speaker at the Oley Foundation meeting in 2011 where Dan explained in layman's terms his research on a piston system designed to stretch the intestinal length as an eventual treatment for patients with short bowel syndrome. The caregivers and home parenteral nutrition $(\mathrm{PN})$ consumers, many of whom in fact carry the diagnosis of short bowel syndrome, understood completely his research to date and how he envisioned the next steps. The fact that the effort had taken 10 years, with collaboration between physicians and engineers, spoke volumes to Dan's comprehension of the realities of life with short bowel syndrome. The standing ovation that followed his presentation was intense and heartfelt. He was a surgical research hero that day.

In my overlapping time with Dan on the ASPEN Board of Directors, his ardent support of issues that concerned patients was never a surprise. Not only was he passionate about best quality care, but he also published many of the most insightful and useful studies in our pediatric nutrition support literature. Dan was supportive of every member of the Board of Directors during his term as president. An unparalleled role model, he is deeply missed.

\section{Stanley J. Dudrick, MD; First ASPEN President 1977}

I join you and all of our colleagues in sharing the beautiful, accurate, and appropriate sentiments that you conveyed to us regarding the passing of our respected and loved friend, Dan Teitelbaum. The value of one's life is not measured by the

From ${ }^{1}$ Department of Biobehavioral Health Science, University of Pennsylvania School of Nursing, Philadelphia, Pennsylvania, USA; ${ }^{2}$ Yale University Medical School, New Haven, Connecticut, USA; ${ }^{3}$ Feinberg School of Medicine, Northwestern University, Chicago, Illinois, USA; ${ }^{4} \mathrm{Mt}$ Carmel West Hospital, Columbus, Ohio, USA; ${ }^{5}$ Department of Pharmacy Practice, Harrison School of Pharmacy, Auburn University, Auburn, Alabama, USA; ${ }^{6}$ Division of Endocrinology, Diabetes, Metabolism and Nutrition, Mayo Clinic, Rochester, Minnesota, USA; ${ }^{7}$ Rhode Island Hospital and Alpert Medical School of Brown University, Providence, Rhode Island, USA; ${ }^{8}$ Department of Nutrition, Brigham and Women's Hospital, Boston, Massachusetts, USA; ${ }^{9}$ Alpert Medical School of Brown University and Hasbro Children's Hospital, Providence, Rhode Island, USA; ${ }^{10} \mathrm{C}$. S. Mott Children's Hospital, Ann Arbor, Michigan, USA; ${ }^{11}$ Department of General Surgery, Xinqiao Hospital, Third Military Medical University, Chongqing, China; ${ }^{12}$ Skaggs School of Pharmacy and Pharmaceutical Sciences and Children's Hospital Colorado, University of Colorado Anschutz Medical Campus, Aurora, Colorado, USA; ${ }^{13}$ Department of Kinesiology and Nutrition, University of Illinois at Chicago, Illinois, USA; ${ }^{14}$ University of Michigan Health System, Ann Arbor, Michigan, USA; ${ }^{15}$ Children's Intestinal Rehabilitation Team, University of Michigan C. S. Mott Children's Hospital, Ann Arbor, Michigan, USA; ${ }^{16}$ Home Care Nursing, University of Michigan Health System, Ann Arbor, Michigan, USA; and

${ }^{17}$ HomeMed Home Care Service, Ann Arbor, Michigan, USA.

Financial disclosure: None declared.

Conflicts of interest: None declared.

*On behalf of the University of Michigan C. S. Mott Children's Hospital, Children's Intestinal Rehabilitation Team

Note: Authors are listed in the order in which their contributions appear. In addition to the authors listed here, the journal gratefully acknowledges the contributions of an anonymous caregiver and patient's family.

This article originally appeared online on October 6, 2016.

Corresponding Author:

Charlene Compher, PhD, RD, CNSC, LDN, FASPEN, Professor of Nutrition Science, University of Pennsylvania School of Nursing, Philadelphia, PA, USA.

Email: compherc@nursing.upenn.edu 
quantity in length but rather by the quality of its content and contributions. Dan's was indeed a life of the highest quality, which will far surpass its quantity in length. As a Dudrick Research Award Scholar, Dan has already honored me and will continue to do so ad infinitum, as part of his legacy. Humanity has prematurely lost a great and precious champion. His legacy will live on among us, and among his, and our successors. God bless him and his family.

\section{John R. Wesley, MD, FACS, FAAP, FASPEN; ASPEN President 1993}

I was privileged to know Dan over many years, from 1992 until his untimely death on August 17, 2016, after a prolonged struggle with brain cancer. Our professional relationship included both the practice of pediatric surgery - taking care of infants and children at Mott Children's Hospital in Ann Arbor-and the art and science of nutrition support through our working and serving together on the various committees, workshops, and leadership roles in the American Society for Parenteral and Enteral Nutrition (ASPEN). He brought his considerable talents as a caring physician-surgeon and discerning scientist to all of his relationships, both with patients and their families, and with his many residents and fellows in the laboratory and colleagues in the vineyards of surgery. In my academic and clinical collaborations with Dan, he continually impressed me with his eagerness to improve patient care, to push for increased knowledge in order to better understand and solve problems encountered at the bedside, and by his love for teaching, both in the operating room and as physician-director of the parenteral and enteral (PEN) team at the University of Michigan. Most important, we developed a friendship that thrived over the years as we explored a wide range of ideas and personal thoughts.

I was able to visit Dan and his wife, Mindy, during his final illness, and we shared many fond remembrances of happier times. As he has always been dedicated in his ASPEN leadership role to providing research funding for young investigators and an early proponent for the Rhoads Research Foundation, it was particularly appropriate that ASPEN establish a research grant in his honor at the Clinical Nutrition Week in January.

Dan leaves a wonderful legacy! He will be missed! We will always keep him, his wife, and their 3 daughters in our thoughts and prayers.

\section{Ainsley Malone, MS, RD, LD, CNSC, FAND, FASPEN; ASPEN President 2014}

In all of our discussions involving ASPEN activities and decisions related to those activities, Dan would always bring things back to the membership. Would there be a benefit to the ASPEN member regardless of discipline, age, or involvement in the organization? This was a driving force in all of his conversations. Dan was an inclusive and empowering leader. He led by being empathetic, humbling, and inspirational.

\section{Gordon S. Sacks, PharmD, BCNSP, FCCP; ASPEN President 2015}

On August 17, 2016, the field of clinical nutrition lost a great man, scientist, and practitioner with the passing of Dan Teitelbaum, MD. I first met Dan when I was elected to the ASPEN Board of Directors in 2012. I was struck by his thoughtfulness, attention to detail, and ability to bring all members of the board to consensus on contentious issues. In 2014, I became the president elect of ASPEN while Dan assumed the position of president. During this time, I had the opportunity to work more closely with Dan on a variety of issues and travel around the world to international clinical nutrition meetings to represent the interests of ASPEN and its members. Dan and his wife, Mindy, often invited me to accompany them on sightseeing tours when extra time was available to enjoy local tourist sites. This gesture was emblematic of Dan's persona in that he was always willing to share his time and energy with fellow friends and colleagues. As I traveled around the world, I discovered that Dan had served as a mentor for many pediatric surgeons from outside the United States, especially from China. Dan had invited numerous Chinese surgery fellows to study and work in his research laboratory. As a result, Dan forged a close relationship with the Chinese Society for Parenteral and Enteral Nutrition (CSPEN), and before his death, they recently honored him by granting him an honorary membership in CSPEN. Dan's impact on the field of clinical nutrition will never be forgotten, and the ASPEN Rhoads Research Foundation has honored his life and exceptional accomplishments by naming one of its grants the Daniel $\mathbf{H}$. Teitelbaum Research Grant in commemoration of his incredible life and dedication to the field of nutrition. Personally, Dan had a tremendous influence on my life, both personally and professionally, and I am truly blessed for having had the opportunity to call him my friend and colleague.

\section{Molly McMahon, MD; ASPEN President, 2017-2018}

I had not been as involved with ASPEN in the recent past before joining the board. Dan was president when I joined. He called me before the first meeting to orient me. I sat next to him at dinner the Friday night before we had our meeting. He called me after the first board meeting to say thanks for being willing to speak up at my first meeting. That interest and encouragement were so important to me. What I observed during the year of his presidency was an extremely humble and thoughtful person who would listen to each of us at board meetings. It was clear he respected each person greatly. He was not afraid to take a stand when he felt strongly about an issue, but he always responded with such carefully thought-out words. He is one of 
a small number of physicians in the current medical climate who was able to successfully bridge a career filled with research, clinical practice, and administration. I know I was blessed to get to know him during that one year. The field of nutrition, each of us in ASPEN, and his patients were and are better off because of Dan Teitelbaum.

\section{Marion F. Winkler, PhD, RD, LDN, CNSC, FASPEN; President, ASPEN Rhoads Research Foundation; ASPEN President, 2006}

In January 2016, the Board of Directors of the ASPEN Rhoads Research Foundation established the Daniel H. Teitelbaum Research Grant to honor Dr Teitelbaum's professional accomplishments, leadership, and mentorship to students, residents, fellows, and colleagues. This is a small tribute in comparison to the tremendous impact Dan had on ASPEN's research agenda and on research in PN, intestinal failure, and surgical metabolism. In his presidential address, Dr Teitelbaum challenged the profession and ASPEN to increase funding for medical research in general and nutrition and metabolic research in particular. Dan communicated to Foundation President Marion Winkler, $\mathrm{PhD}, \mathrm{RD}$, that he was "moved by this tribute," "honored," and "appreciative of our desire to support the efforts of young investigators."

\section{Kris M. Mogensen, MS, RD, LDN, CNSC; Director, ASPEN Board of Directors}

I'm very sad that I didn't have the opportunity to work directly with Dr Teitelbaum. He was a stellar ASPEN president, and I remember how much I enjoyed his presidential address, particularly how he included his daughter in the Jeopardy part of his talk. It was so much fun! I loved that he brought Doug Wilmore back to ASPEN, which clearly energized the conference. Hearing the other board members talk about him, he so obviously was an outstanding leader, researcher, mentor, and friend to those who knew him in all aspects of his life. It's so devastating to lose such an important person in our field, who was still so young and had so much to give. I'm sure this quote can be contributed to others, but my mother always says that you keep a lost loved one alive in your memories. Not only do we have memories of Dr Teitelbaum, but also his mentees will be able to carry his memory and vision in their own work.

\section{Arlet Kurkchubasche, MD}

Daniel Teitelbaum was one of the most multidimensional and precious surgeons I have had the honor to know. He was a truly respected colleague in general and pediatric surgery with all the attributes of the compassionate, engaging surgeon a family wants to see for their child. As a surgeon, he had such a vast experience and knowledge base that no one could challenge him. As a teacher and mentor, his mind was always at work, always listening to others, reflecting their thoughts and developing new questions that would stimulate further efforts. As a scientist, he was always curious, continuously challenging and seeking to understand what placed our patients at risk.

He treated everyone in such a gentle and respectful manner. I particularly remember his concern for his laboratory personnel who came from many corners of the world and how he guided them through conferences and meetings. He was enthused to be around investigators from all fields, whether residents in surgery, pharmacists, dietitians, or medical specialists. As such, he was the perfect person to lead ASPEN. He was selfless and loved his family. His pride showed when talking about his daughters, and I can imagine what a great dad he was to them. He will be missed by so many, but he has left us with his legacies.

\section{Meghan A. Arnold, MD}

Dan Teitelbaum was many things - dedicated husband, proud father, avid gardener, adventurous world traveler, prolific researcher, and a technically gifted surgeon - but what he loved most was taking care of medically complex children and their families. He listened to their needs and wishes, he thoughtfully planned the course ahead, and he strived to achieve common goals of health, happiness, and quality of life.

Every aspect of his career brought him joy, and he was at his best when he was teaching and passing on his vast knowledge of pediatric surgery. Dan was an incredible and persistent mentor to residents, fellow and faculty alike. His office door was always open, and he thrived on talking through a difficult case. His eyes lit up with every new discovery in the laboratory or when one of his trainees published a paper or presented at a national meeting. His enthusiasm for his work was infectious. His dedication to his patients and their families was exemplary.

As one of his fellows and then one of his surgical partners, I had the privilege of working alongside him in the operating room, in the clinic, and on various research projects. He pushed me to accomplish more at this point in my career than I thought possible. He embodied the empathy, professionalism, skill, and dedication we all aspire to as surgeons. Our pediatric surgery family isn't the same without him, but we are better people and better surgeons for having had him in it.

\section{Hua Yang, MD, PhD}

Dr Teitelbaum was my mentor when I first worked at the University of Michigan. The most respected and considerate man I have ever met, I cannot find words to fully express my level of admiration and appreciation for him. In July last year, I was informed by a former colleague that Dr Teitelbaum was recently diagnosed with brain cancer. Upon receiving this news, I flew to the United States to see him. Since then, I had always wished for him to see fruitful results from his treatment and hoped that he would experience a smooth recovery. I did not expect that to be the last time that I would see him. I was 
shocked when the sad news came a year later. It seemed unbelievable that I would lose a mentor and a great friend so abruptly.

I came to know Dr Teitelbaum through my work in the late 1990s. I had stumbled upon Dr Teitelbaum's publications while doing research at Linkoping University in Sweden. Coincidentally, Dr Teitelbaum and I held similar research interests in the field of intestinal barrier and gut immunity. I was lucky to have then been invited to work in his laboratory in 1999 and enjoyed the next 8 years learning from him and collaborating with him.

I can confidently say that Dr Teitelbaum always kept to his core values and easily maintained the status of both a gentleman and a scholar, inside and outside of laboratory. I continue to follow in his footsteps in how he directed weekly laboratory meetings by encouraging collaboration and helping others to view challenges from new perspectives. His ability to help others accomplish groundbreaking work by themselves is surely a reason for the success that I and many others enjoy today. Under his encouragement, my research work progressed smoothly, and twice I received the "Harry Vars Award" (2002, 2003) from ASPEN and was granted a Maurice Shils grant from the ASPEN Rhoads Foundation in 2004.

While Dr Teitelbaum's laboratory was filled with talented individuals of all nationalities, it never felt foreign to me for he was always mindful of ensuring that everyone felt at home. I will always cherish the holiday parties and dinners that the entire laboratory bonded over. Even after leaving his laboratory, I always felt welcomed whenever I came back for a visit. I'm blessed to have always felt that I was a part of the team, even after my departure.

Dr Teitelbaum still cared about my research after I went back to China, and he visited my institution twice after I had returned there in 2007. Under his great guidance, support, and help, we were able to secure support for an international joint research project funded by the National Natural Science Foundation of China. A total of 16 research papers were published under the support of this grant, and we won the first class of Chongqing Natural Science Award, the first within our institute. Furthermore, Dr Teitelbaum's influence and leadership also forged and strengthened international relationships between the Chinese Society of Parenteral and Enteral Nutrition (CSPEN) and ASPEN, which led to countless breakthroughs and ongoing discoveries. Dr Teitelbaum's absence will surely be felt by researchers around the globe. While he is no longer with us, his compassion for those around him, his academic acuity, and his legacy will continue to echo through those who has had the chance to work and learn from him.

\section{Allison B. Blackmer, PharmD, BCPS}

Very early in my professional career, I had the great fortune of working with Dan Teitelbaum. I was a new clinical faculty member at the University of Michigan, and he quietly took me under his wing and encouraged me to push myself in ways I would not have thought possible. He inspired me to find my clinical and research passions and gave me the confidence to believe that I was capable. He set the wheels of my professional career in motion and helped me achieve more in the first few years of my clinical and academic practice than I thought possible in a lifetime. He showed me how to ask difficult questions and seek the answers.

Dan's style of mentorship was not one of verbose advice but rather a few very carefully crafted, well-thought-out, and deliberately delivered words. I will always remember how he would listen intensely, close his eyes, and then, with his fingers intertwined before him, say a few words that got to the heart of the matter. While I may not be able to articulate this tribute in this same way, I will do my best. Dan's gift of mentorship is one that I will always feel lucky and grateful to have received. I can honestly say that I am (we all are) better to have known him. His life and his contributions deserve celebration and honor. He was an inspiration.

Dan Teitelbaum truly epitomized a great man and mentor. He touched the lives of many, and he will be remembered and honored for the countless ways in which he devoted his life to improving the lives of others, some of them more tangible than others. His ability to identify potential, inspire and push, stimulate passion, encourage confidence and belief, and unconditionally support was subtle yet powerful. These are the gifts for which I will always be thankful and for which the words that express gratitude are simply not enough.

\section{Carol Braunschweig, PhD, RD}

I was fortunate to work with Dan in 1994-1996 while he was the director of the University of Michigan PEN Team. I was in the final phase of my $\mathrm{PhD}$ training and will always remember his caring, compassionate methods that were the foundation of his patient care as well as his interactions with the team members. He was a brilliant, kind, interested man that radiated a moral sense that transformed any room he was in (the board room, laboratory, bedside, or at a dining room table). A conversation with Dan felt like time spent simultaneously at a think tank and a spa. I felt mentally enlightened, contemplating new questions or implications from various studies and simultaneously refreshed from his words.

It has been said that music is the universal language that touches us where words alone cannot. I believe this describes the "Dan effect." He was generous with his time, heart, mind, and strength, and I believe these attributes compelled any of us fortunate enough to have known him to strive to be our very best selves. While his life was far too short, I will never forget the impact it has had on methis I know for sure. 


\section{Theresa Han-Markey, MS, RD}

Dan-isms:

Ability to do 360's with his pen across his fingertips at any meeting.

"Mopping of the brow" when nutrition support issues became stressful.

Overabundance of patience dealing with trainees and nutrition team members and never losing his temper or yelling at me. Rather, he would discuss and point out differences in a quiet, authoritative manner.

Creating an inviting, collegial atmosphere where each of our input was valued.

Just being a nice guy, nice enough where I always wanted to assist in any request he made for the sake of research or patient care.

\section{Luisa Partipilo, PharmD, BCNSP, and Mary Beth Harris, MPH, RD, CSP, CNSC, on behalf of the University of Michigan C. S. Mott Children's Hospital, Children's Intestinal Rehabilitation Team}

As one of the original founders of the Children's Intestinal Rehabilitation Program (ChIRP) at the University of Michigan C. S. Mott Children's Hospital, Dr Teitelbaum (aka "Dr T") made so many contributions to the care of children with intestinal failure that it is difficult to capture with words all that he meant to our team, patients, and families. Upon meeting Dr T, one could immediately sense the passion he had for this program - and it was contagious. He was passionate about all aspects of patient care, not just the surgical issues. He listened to each member of the team and gave us all the same amount of respect. We all felt like equal members of a family unit. He pushed us to always be better and challenged us to think outside of the box and to be creative in our solutions for patients. After being stumped on how to treat a PN-dependent patient's vitamin deficiency, he simply said, "Triple the vitamins and monitor levels." This was a strategy that was not apparent to the rest of us, because it is not conventional treatment, but ended up working very well for that particular case. When families came to him with unconventional ideas for treatment, he listened intently and found ways to incorporate their wishes whenever possible without compromising patient safety. He made our patients and their families feel like a valued part of the team. He was humble, always trying to give us all the credit for patient successes. For example, he once tried to get us to take his name off a publication he was very much involved in, because he wanted the entire attention to be on his team. Dr T was also known among our team members to be incredibly supportive and kind. He attended every poster session, roundtable, or presentation we gave, whether at ASPEN Clinical Nutrition Week or local. We could always look to him to contribute his knowledge about the topic being discussed. He cared for each of us on a personal level, always happy to listen to our rambling stories about our outside lives and sharing some of his own. We are all better clinicians and better people for having known him. As we move forward in our careers, we will always be thinking, "What would Dr T do?"

\section{Deb Kovacevich, MPH, BSN, RN}

To describe Dan and the many contributions he made to me and our home care programs is very difficult, but a few words come to mind: mentor, cheerleader, educator, kind, excellent surgeon, researcher, supporter, an incredible mind, friend, and, most of all, a patient advocate. I will sorely miss the many lively conversations in which he challenged all of us to think and act higher in regards to providing the highest quality care to our patients!

Dan brought so many gifts and touched so many people's lives. He truly loved the nutrition and home care communities.

\section{Bonnie Peters, RN}

Dan was so instrumental in all of us becoming part of a special family. I will always be indebted to him for his kindness and helping me learn as much as I can and to make a difference in patients and their families. I knew when I was in this that it would always be my favorite part of my career-thank you, Dan, for being a major part of it!

\section{Alexis Cantwell}

Having been one of Dr Teitelbaum's oldest patients, I had the privilege of establishing a connection with him since the time I was 12 years old, and allow me to say-that connection will last a lifetime. Although Dr Teitelbaum is no longer with us, helping and changing the lives of others like he did mine, he will always be with us in our hearts. He was a very special man who took great pride in his work and caring for every single one of his patients and their families to ensure that they were given the best chance at a healthy lifestyle. I can say this, because he did this for myself.

When I first came to Dr Teitelbaum, we weren't sure if he was going to be able to help me get healthy again, but we had faith in him and his abundance of knowledge and that he would be the one who would save me, more or less. Needless to say, he did just that. At just 12 years old, my parents were desperate to seek a better lifestyle for me, and Dr Teitelbaum provided me with that lifestyle. After lots of research, numerous procedures, and the upmost confidence, I was back on the right track to being healthy.

One particular thing that I especially cherished about Dr Teitelbaum was how he talked to his patients and their families and how he ensured that every single step in furthering his patients' care was understood not only by the parents but also, in my case, the patient; I always felt like I was that much more 
educated after every appointment and procedure, because he took the time to talk with me and my family on a level that we understood.

I will never forget Dr Daniel Teitelbaum and all that he did for me and how his abundance of knowledge in research will continue to help me and my diagnosis of Hirschsprung disease. I am now 23 and pursuing a degree in elementary education, and I have been on PN for practically my whole life, and without his knowledge and impeccable skill, I am certain that I wouldn't be living the life I am today; I owe the life that I'm living to him, a man who was greater than words can describe.

\section{Caregiver}

Rare. An adjective meaning unusual, uncommon.

My daughter, Emmy, is rare. The kind of rare that makes a mom question the legitimacy of statistics. The kind of rare that tends to bring the unexpected along with it.

Rare. An adjective also meaning unusually great, excellent, admiral, fine.

Dr Teitelbaum was rare. It is hard for me to put into words exactly what his care meant to us. He was the physician I knew was always truly listening. He was the physician that I could rely on to help us navigate new or worsening conditions. He was the physician that easily admitted he was worried heading in to perform surgery on our daughter, letting us know that she was more than just a name on his schedule that day. He was the physician that would come into the clinic for the sole purpose of seeing Emmy on a day when he already had other things on his schedule. He was the physician that came into her hospital room every day after surgery to check on her, offering not only his medical expertise but his time and his prayers.

His devotion, passion, brilliance, and kindness will be so missed. We are forever grateful for his care and can only hope that he knew just how very highly we thought of him. He was unusually great. Excellent. Admiral. Rare.

\section{Patient's Family}

\section{You Are the Wish We Needed}

We met under strange conditions. You were a mystery-one calling the shots yet out of view. My first look at you in the neonatal intensive care unit (NICU) searched, begged . . . for you to tell me it will be alright. The words escape me but your presence spoke all I needed to know. You gave me a sliver of light in such a dark place. You see, all before you had advised us to let go. You allowed me to open my heart to my son with two rare illnesses and not be afraid of what was to come.

If I chronicled our moments together, I think I have a picture that is a masterpiece. Full of mistakes and breakthrough ideas, it has led to a full life for my son. He has always been your first priority. You think of him on vacation, your day off, and in the heat of surgery. I remember you coming to Mott one
Saturday afternoon, just to see how Quinn was feeling. I did not confide to you then how low of a place I was in and how you lifted me to believe again. Most of our talk was and is medical. I guess I always tried to hide my emotions because I was scared to release to a place I did not know how to recover from. What you taught me in those moments was how to be strong, to push forward and see options.

Jim and I talk about why you hold a deep place in our hearts. What makes you different from all the medical professionals we see. Many reasons are forefront, and two have made all the difference. You LISTEN. You take my jumbled words and quickfire reports to blend them as a viable treatment plan for Quinn. You seek from all ends of the earth ways to make life better for our family, for Q. You BELIEVE. It has never been a question to you if Q will live. You know he will. Your eyes portray hope even in the moment you told me you thought there was nothing left to do but transplant. I questioned why you told me that for so long, and I feel we both realized that fate brought Quinn to us, to push our boundaries to a place neither of us knew how to navigate. You rose to the challenge, and at that moment, I realized you are a man with true love for my son.

Losing your Magic Man. Quinn's love for you is reciprocated. When he found out he could visit you, it took him a week to decide. He suddenly announced he wanted to see you, then held me forever as he sobbed. I never told him how ill you were - it was instinctive for him. On our first visit, we were all so nervous. You ... so gracious. You offered the boys candy and Q gave you a painting. Your eyes lit up like they always did in clinic. The joy between you two floated around the room. A subsequent visit, we shared your favorite pizza - onion and garlic. Desmond ate a piece-it's now his favorite. He is 9 . Both he and Q wish to bring a pizza to your gravesite, Des's idea. And he was never your patient. I think about how hard it is to capture the essence of what you mean to us, yet the simplicity of the stories you leave our family ground us to continue living the tenets you showed to us all — faith, trust, and love.

\section{We Learn Love From Dr Teitelbaum}

\section{By Mary Ann Fithian, Parent of a Patient}

We've been on this journey over 6 years now - a journey that has been filled with the darkest and lightest days of my life. A journey that has been blessed with the most amazing people God could have ever chosen to accompany us. Today, one of those people left us. He's the person I tell people saved my Faith.

So, while I know that this loss is inconceivably hard to his family, friends, and his colleagues, I will do my best to tell you what the loss of Dr Teitelbaum means to us, a family who was blessed with his brilliant mind and masterful care and thoughtful education of those who will continue to care for our Faith. 
I think that it would be easy for me to ask WHY - and HOW-could something like this happen. It's unbelievably hard for me to not angrily question how someone like this man, who prevented suffering and death of children, could be taken from us, but when I think about Dr Teitelbaum and the way he was, I know that he would want me to instead concentrate not on his death but on his life and how he chose to live and how we can learn.

Faith's case is complicated. And from the beginning, Dr Newman told us about this amazing doctor that worked at Mott who specialized in the care of diseases like Faith's. She said he was one of the best in the nation. In fact, she may have said he was the best, and after years of working with him and meeting many of his colleagues around the nation, I'd have to say she was right. He was the best.

That may seem like a bit of an inflammatory statement. But I assure you that it is not. It is the same opinion held by countless other mothers of children who have been cared for by him.

It's possible, probable really, that you will never understand the unbelievable fear you have when you have a sick child who just isn't getting better. That was my Faith at the beginning of her diagnosis. We knew what was making her sick, but the treatments that should have made things better just weren't working, and I was so scared.

When we first met Dr Teitelbaum, he wanted to know everything. With his hand on his face, he would sit back and LISTEN to every word we said. He always really listened. He rushed nothing, and he would hear every word. As a parent, you worry that you will tell them all that they need to know, that you will tell them enough, that you won't leave out an important detail; with Dr Teitelbaum, that was never a worry, because there was no rush, ever.

\section{From him we can learn to LISTEN.}

As time passed, I learned something from Dr Teitelbaum that surprised me. I learned that while I wanted the doctors on Faith's team to be confident, it was extremely important to me that they were humble. The saying "you only know what you don't know," well, Dr Teitelbaum never answered a question he didn't know the answer to. Maybe that seems like an obvious statement, but it's not. If there isn't an answer, and it's just your opinion, I want to know that. He was always looking things up on his phone or getting back with me after he had done some research. Sometimes he would call his colleague from the other side of the world to get his opinion on Faith.

From him we can learn to be HUMBLE.

When you have someone who is willing to tell you that he doesn't know the answer to every question you have but is always willing to find an answer, it builds TRUST. When you have a child with a chronic illness, sometimes you try things that work well, and sometimes things don't. There is an art to medicine; it's not always cut and dry. Dr Teitelbaum built trust with Faith, and he built trust with our family. I always trusted his opinions and always felt assured after talking to him that Faith was in the most capable hands. When he left the room, I always felt like we had a plan, and it was one we could live with; I trusted him.

From him we learn to build TRUST.

I can tell you that when you have a rare disease, your healthcare team literally works around the clock for you. Sending photos and questions happens more often than I would like. The great thing is having a doctor that will answer your question at $2 \mathrm{AM}$ - what a reassurance. What was also reassuring was that he wanted to learn more and more. He would come into the room and say, "I was reading this study and I wanted to go over it with you." Then he would open up a medical journal and read a study with us. Many doctors would give us the results without explaining how they came up with them, but Dr Teitelbaum understood that, as Faith's mom, I was his most important student about her disease, and he challenged me to understand what I was reading.

Dr Teitelbaum wasn't practicing medicine for the last year of his life, so it had been a while since we had seen him, but he would be happy to know that I've kept up with reading the medical journals and studies that he taught me about. Parents who want to know everything there is to know do not make doctors' jobs easier; I know for a fact that I can be a pain in their side, but Dr Teitelbaum taught me that learning to learn was one of my most important jobs as Faith's mom.

From him we can learn to LEARN.

Our first week in-house at Mott was tricky. I took to Facebook to ask what a resident and attending doctor even meant. Quickly, I learned the ranks, but something I respected so much about Dr Teitelbaum is the way he taught. He would speak with the same respect to a first-year medical student as he would his fellow attending physicians. His style of teaching was all inclusive, and he involved Faith as much as he could. One day when he left rounds in our room, my girlfriend, who is a teacher, said to me, "I think I just got the best lesson in education in my entire life," and I believe her. His teaching style is one of the things about him that can never be replaced but certainly carried on by his students.

\section{From him we learn to TEACH.}

The last thing I want you to know about this man who we will miss so much involves a story. When Faith was 6, it was determined that her colostomy bag alone wasn't doing the job and 
her entire colon would have to be resected. It was a scary surgery as they had to also do some work on arteries that supplied the blood to the lower part of her body. I handed her off in the care of Dr Newman and Dr Teitelbaum. They thought it could take as much as 6 hours to compete. Faith was an expert at the operating room (OR) at this point and didn't need the premed to go back to the OR. As they wheeled her away, I listened to her talk to her doctors.

Three hours later, we received a page. The doctors wanted to meet with Faith's dad and me in the consultation room. I remember looking at each other, scared out of our minds that it went so fast that something had to have gone terribly wrong. When we got to the room, Dr Teitelbaum pulled out his phone and said, "I want to show you something."

I gasped for air and then looked at the smile on his face. NO WAY was something wrong - he was beaming, with a smile from ear to ear. He showed us a video he had taken of Faith singing in the OR just before she had her surgery. She sang to him about going bowling with her colon, with a big smile and lots of dramatic hand gestures. She understood how serious this surgery was, but she trusted her team that much! That she took the time to make up a song for them apparently was a first for him, because he was pretty excited about it. He asked our permission to share the video, and said it had a great impact on him.
He then shared that the surgery was a success and she was doing fantastic, but I loved that he couldn't wait to share the video with us, not to tell us about how amazing they had just done in the OR but how amazing our daughter was to him.

Dr Teitelbaum knew he was leaving us and made sure that his patients were going to be well taken care of in his absence. I truly believe there is no replacing this man, but I know Faith is in very capable hands. I fear the day I have something new come up, and the reality of him being gone takes my breath away like it did when I first heard about his illness.

I mourn the fact that his brilliant mind isn't working on curing Faith's disease. I will miss seeing him and having him watch Faith grow. I tried really hard to reach out to him once I heard about his diagnosis to thank him for everything he had done for Faith, but how do you thank someone for giving life when they are losing theirs? Luckily, I have strong spiritual faith that this man now knows exactly how strongly I felt about him and what he has done for our family.

When I told Faith that Dr Teitelbaum had died, she was pretty hysterical. Worse than I had expected because we knew he was going to die. Once she had calmed down, I asked her what about it made her so sad and she said, "I just know he really loved me, Mom, and I really loved him."

From him we learn LOVE. 